\title{
IDRIJSKO HRIBOVJE KOT PRIMER DEMOGRAFSKO OGROŽENEGA OBMOČJA
}

Monika Benkovič*

\section{Izvleček}

V prispevku je prikazana analiza kazalcev: gibanje števila prebivalcev in indeks staranja, s katerima se v Sloveniji opredeljujejo demografsko ogrožena območja. Omenjeni so tudi nekateri vzroki in posledice neugodnih demografskih gibanj na območju Idrijskega hribovja.

Ključne besede: Idrijsko hribovje, demografsko ogrožena območja, mreža šol, centralna naselja.

\section{IDRIJSKO HRIBOVJE REGION AS AN EXAMPLE OF DEMOGRAPHICALLY ENDANGERED AREA}

\begin{abstract}
The article analyses two criteria: rate of growth of population and ageing index, which in Slovenia define demographically endangered areas. There are also mentioned some causes and consequences of unfavourable demographic trends in Idrijsko hribovje region.
\end{abstract}

Key words: Idrijsko hribovje, demographically endangered areas, school net work, central settlements.

\footnotetext{
* Dipl. geogr., mlada raziskovalka, Oddelek za geografijo, Filozofska fakulteta, Aškerčeva 2, 1000 Ljubljana, Slovenija
} 


\section{Uvod}

Idrijsko hribovje je del sredogorskega sveta na prehodu iz alpskega $v$ dinarski svet. Severno mejo predstavlja reka Bača, na zahodu poteka meja po Trebušici, na severozahodu po Idrijci, južna meja je reka Belca, vzhodna Idrijca, na severovzhodu pa je meja s Cerkljanskim hribovjem precej nejasna (Černe, 1998). Območje obsega 239 km2 in 29 naselij. V analizo so bila vključena vsa naselja, razen Idrije, Spodnje Idrije in Spodnje Kanomlje. V Idriji živi dobra polovica ljudi, če prištejemo še Spodnjo Idrijo in Spodnjo Kanomljo, ki je neposredno povezana z njo, sta to že več kot dve tretjini prebivalstva obravnavanega območja. Ker ta naselja zaradi bistveno drugačnih gospodarskih pogojev kažejo drugačno demogeografsko sliko kot hriboviti predeli, so bila izločena iz obravnave.

Obravnavano območje se deli med tri občine: Cerkno, Idrija in Tolmin.

Zaradi razgibanega površja, skromnih naravnih možnosti za gospodarski razvoj in odročne lege je pokrajina redko poseljena. Leta 2000 je bila gostota $47 \mathrm{ljudi} / \mathrm{km} 2$, če odštejem prej omenjena naselja, pa gostota znaša le 15 prebivalcev/km2, kar je 6,5-krat manj kot je povprečje v Sloveniji. Poselitev se je v Idrijskem hribovju osredotočila na planotah in na terasah $v$ pobočjih. Dna dolin so ozka, zato za naselitev niso bila primerna. Večje vasi so na ravnih delih planot, kjer je bil tudi prostor za obdelovalne površine. Do kolonizacije tega območja je prišlo relativno pozno; zaradi oddaljenosti od pomembnih prometnih poti je bilo hribovje še konec srednjega veka neposeljeno. Samo Šentviška in Šebreljska planota sta bili poseljeni prej, na kar kažejo zgodovinske najdbe. Gostejšo poselitev je šele v 16. stoletju prineslo rudarjenje, ki je dalo pečat razvoju poselitve vse do današnjih dni. Gosteje naseljeno je le območje Idrije in Spodnje Idrije, kjer je dolinsko dno širše, povsod drugod pa gre za manjša naselja in samotne kmetije, ki so nastale med rovtarsko kolonizacijo (Černe, 1998; Melik, 1960).

Namen prispevka je analizirati gibanje števila prebivalcev $v$ naseljih Idrijskega hribovja, določiti indekse staranja prebivalstva ter ugotoviti vzroke preteklih in sedanjih demografskih procesov, njihove posledice in vpliv le-teh na prihodnji razvoj. Kot pomemben dejavnik ohranjanja poselitve so predstavljena centralna naselja in mreža šol. Uporabljeni so bili podatki popisov prebivalstva za leti 1961 in 1991, podatki Statističnega urada RS o prebivalstvu za leto 2000 in rezultati terenskega dela. $V$ analizo so bili vključeni naslednji kazalci:

- gibanje števila prebivalcev v obdobju 1869 - 2000, s poudarkom na 
obdobju 1961 - 2000;

- starostna sestava prebivalstva leta 1961, 1991 in 2000 (indeksi staranja);

- delež kmečkega prebivalstva leta 1961 in 1991;

- izobrazbena sestava prebivalstva leta 1991;

- mreža osnovnih šol leta 1961 in 2001;

- razporeditev centralnih naselij in njihova opremljenost.

Kovačič (1994) v območjih depopulacije našteva naslednje probleme: staranje in zmanjševanje števila prebivalcev, slabša oskrba in infrastrukturna opremljenost, zmanjševanje obsega in intenzivnosti kmetijske pridelave, hitro zaraščanje mejnih kmetijskih zemljišč, propadanje proizvodnih potencialov kot tudi gospodarske in socialne infrastrukture, stavbnega fonda in kulturne dediščine. Vsi ti problemi se pojavljajo tudi v Idrijskem hribovju, vendar zaradi obsežnosti problematike njihova natančna predstavitev $v$ tem prispevku ni mogoča.

\section{Opredelitev demografsko ogroženih območij}

Slovenija je, ne glede na ozemeljsko majhnost in skromno število prebivalstva, geografsko, gospodarsko in socialno raznolika država. Zato ni presenetljivo, da so tudi regionalne razlike velike. Nastala so manjša območja, kjer se je zgostilo prebivalstvo, gospodarstvo in infrastruktura ter območja zaostajanja, kjer prevladuje kmetijstvo, slabša oskrba in infrastrukturna opremljenost. Do sedemdesetih let 20. stoletja so se razlike večale, potem pa so se začele zmanjševati, h čemur sta najbolj prispevali politika skladnega regionalnega razvoja in policentrična naravnanost upravljanja države. Regionalne razlike so se začele znova večati v drugi polovici osemdesetih let zaradi splošne družbene in gospodarske krize in $v$ devetdesetih letih zaradi spremembe družbenega reda in z njim povezanih tranzicijskih gibanj (Ravbar, 2000).

Sistematično usmerjanje razvoja v Sloveniji se je začelo leta 1971 s sprejetjem Zakona o ukrepih za pospeševanje razvoja $v$ manj razvitih območjih v SR Sloveniji (UL SRS 16/71). S poznejšimi novelacijami na vsakih pet let so zakon preoblikovali in ga preimenovali $v$ Zakon o pospeševanju skladnega regionalnega razvoja $\vee$ SR Sloveniji (UL SRS 29/75, UL SRS 30/80, UL SRS 33/85, UL SRS 16/86, UL SRS 28/88). Manj razvita območja so dobila pomoč $v$ obliki posojil, davčnih olajšav, pomoči pri gradnji infrastrukture, posebna ugodnost pa je veljala za podjetja, ki so v teh območjih 
odprla nov obrat. Upravičenost do pomoči se je opredeljevala s posebnimi merili, ki so upoštevala ustvarjeni družbeni proizvod, vrednost osnovnih sredstev, delež kmečkega prebivalstva, opremljenost z infrastrukturo in oskrbnimi dejavnostmi (Vrišer, 1998). Do leta 1990 je bil poudarek predvsem na podpori gospodarsko manj razvitim območjem, izenačevanju možnosti za življenje in delo prebivalstva in s tem na zmanjševanju razlik v stopnji gospodarske razvitosti. S sprejetjem Zakona o spodbujanju razvoja demografsko ogroženih območij v R Sloveniji (UL RS 48/90, UL RS 12/92) pa se je pomoč usmerila na obmejna, hribovska in druga demografsko ogrožena območja, kjer se je število prebivalstva že dalj časa nadpovprečno zmanjševalo. Zakon v drugem členu navaja, da se za demografsko ogrožena območja štejejo širša strnjena območja, ne glede na meje občin, v katerih krajevne skupnosti izpolnjujejo naslednja dva kazalca:

- da rast stalnega prebivalstva ne presega $25 \%$ povprečne rasti prebivalstva v Republiki Sloveniji od leta 1981 dalje,

- da je indeks staranja stalnega prebivalstva za najmanj $25 \%$ manj ugoden kot v povprečju Republike Slovenije.

Do ukrepov so upravičena tudi območja naselij, ki so opredeljena kot gorsko-višinska z omejenimi naravnimi dejavniki za kmetijstvo, posebni pogoji pa veljajo tudi za krajevne skupnosti v desetkilometrskem obmejnem pasu. Demografsko ogrožena območja so po tem zakonu obsegala 61 \% površine države in $25 \%$ prebivalstva, kar je ozemeljsko precej več kot prej, ko je bilo upoštevanih več kriterijev in ne samo demografski (Pečar, 1998).

Tabela 1: Delež ozemlja in prebivalstva na manj razvitih in demografsko ogroženih območjih v Sloveniji.

Tab. 1: Share of population and Slovenian territory, defined as underdevel oped and demographically endangered.

\begin{tabular}{|c|c|c|}
\hline Obdobje & Delež ozemlja & Delež prebivalstva \\
\hline $1971-75$ & 18,9 & 18,2 \\
\hline $1976-80$ & 30,0 & 20,7 \\
\hline $1981-85$ & 29,1 & 15,6 \\
\hline $1986-90$ & 21,7 & 16,0 \\
\hline $1991-95$ & 61,0 & 25,0 \\
\hline
\end{tabular}

Vir/Source: Ravbar, 2000;13. 
Država sodeluje pri spodbujanju razvoja demografsko ogroženih območij s sofinanciranjem izdelave razvojnih programov, z davčnimi olajšavami, s spodbujanjem gospodarskih naložb, z zagotavljanjem dela sredstev za razvoj lokalne infrastrukture ter z ukrepi na področju osnovnega šolstva, kulture, zdravstvenega in socialnega varstva ob upoštevanju specifičnosti poselitve in dostopnosti.

Med letoma 1991 in 1999 so izšle štiri uredbe (UL RS 6/91, UL 13/94, UL 45/97 in UL 60/99) o območjih, ki se štejejo za demografsko ogrožena v $R$ Sloveniji in natančno opredeljujejo demografsko ogrožena naselja za obdobje treh let. V vse uredbe je bil uvrščen velik del naselij Idrijskega hribovja. Po zadnji uredbi iz leta 1999 spada 21 izmed 26 obravnavanih naselij med demografsko ogrožena:

- občina Cerkno: Jagršče, Police, Straža, Šebrelje;

- občina Idrija: Čekovnik, Gorenja Kanomlja, Masore, Vojsko;

- občina Tolmin: Bukovski Vrh, Daber, Dolenja Trebuša, Gorenja Trebuša, Gorski Vrh, Idrija pri Bači, Logaršče, Pečine, Ponikve, Roče, Stopnik, Šentviška Gora, Zakraj.

Glavna slabost zadnjega zakona je, da je sestavljen na osnovi le dveh demografskih kriterijev, ki zelo malo povesta o gospodarski moči, socialnih problemih in razvojnih možnostih. Zakon je tako izrazito enostranski, saj zanemarja ostala problematična območja. Celovita regionalna politika pa mora zajeti vse vrste območij s posebnimi razvojnimi problemi in ne le demografsko ogroženih območij, ker je parcialna obravnava posameznih majhnih območij neučinkovita, saj ustvarjanje možnosti za dolgoročno samovzdržujoč razvoj ne pomeni le vrednotenje in aktiviranje vseh lokalnih razvojnih potencialov, ampak tudi povezavo s širšim okoljem (Ravbar, 2000). Celovita regionalna politika naj bi tako kot v večini držav članic Evropske unije opredelila tri tipe območij s posebnimi razvojnimi problemi. Neustreznost sedanjega sistema pospeševanja razvoja demografsko ogroženih območij se kaže tudi v tem, da v času njegove veljavnosti ni prišlo do sprememb $v$ demografski sliki, prav tako pa tudi ni primerljiv $s$ pospeševanjem uravnoteženega razvoja v Evropski uniji. Da bi odpravili te pomanjkljivosti, je bil leta 1999 sprejet Zakon o spodbujanju skladnega regionalnega razvoja (UL RS 60/99), ki uvaja naslednja območja s posebnimi razvojnimi problemi:

- ekonomsko šibka območja,

- območja s strukturnimi problemi in visoko brezposelnostjo,

- razvojno omejevana obmejna območja in območja z omejenimi dejavniki. 
Zakon o skladnem regionalnem razvoju določa, da mora biti v enem letu po njegovi uveljavitvi sprejeta strategija regionalnega razvoja Slovenije (septembra 2001 še ni bila sprejeta) in da se do sprejema regionalnih razvojnih programov, vendar najdlje eno leto po sprejemu strategije, za določitev območij s posebnimi razvojnimi problemi in za spodbujanje njihovega razvoja še vedno uporabljajo pogoji in merila iz zakona o spodbujanju razvoja na demografsko ogroženih območjih.

\section{Gibanje števila prebivalcev v Idrijskem hribovju}

\section{Obdobje od leta 1869 do konca druge svetovne vojne}

Na območju Idrijskega hribovja je ob prvem popisu prebivalstva leta 1869 živelo 8.496 prebivalcev, gostota je znašala 38 ljudi/km2, kar je skoraj 2,5krat več kot leta 2000. Višek števila prebivalcev v vseh naseljih skupaj je bil leta 1880, potem pa je število prebivalcev začelo upadati in še vedno upada. Izjema je bilo leto 1910, ko se je število prebivalcev v primerjavi s popisom iz leta 1900 rahlo povečalo. Do prve svetovne vojne upad števila prebivalcev ni bil velik, bolj je šlo za stagnacijo, kar kaže tudi indeks gibanja števila prebivalcev 1910/1880, ki je 97, če pa primerjamo prvi popis in leto 1910, znaša indeks 100,2. Prebivalci so se ukvarjali večinoma s kmetijstvom; poljedelstvo sta dopolnjevala živinoreja in gozdarstvo. Obdelovanje zemlje na tradicionalen način je $v$ težkih naravnih razmerah zahtevalo veliko delovne sile. Dohodki so bili skromni, saj je pri prodaji lesa in kmetijskih pridelkov težavo predstavljala oddaljenost od pomembnih prometnih poti, zlasti železnice. Svet globoko razrezanih planot je namreč predstavljal veliko oviro za gradnjo prometnih poti, zato so moški odhajali na sezonska dela izven pokrajine.

V času od prve do druge svetovne vojne je ozemlje Idrijskega hribovja pripadalo Italiji in razmere so se še poslabšale. Nove politične meje so zaprle možnost prejšnjega odhajanja na sezonska dela, zato se je povečalo izseljevanje za stalno, predvsem v Združene države Amerike. Precej ljudi je izgubilo življenje med prvo svetovno vojno, izseljevanje pa je pospešila še svetovna gospodarska kriza, čeprav je bil obseg izseljevanja manjši kot v drugih slovenskih pokrajinah (KLS, 1968).

Zmanjševanje števila prebivalcev je bilo $v$ naslednjem obdobju intenzivnejše, k čemur je prispevala druga svetovna vojna, ki je zahtevala veliko 
žrtev, saj je bilo na proučevanem območju močno odporniško gibanje. Na to kažeta tudi indeksa gibanja števila prebivalcev 1948/31 - 81 in 1948/10 - 76.

Grafikon 1: Gibanje števila prebivalcev v Idrijskem hribovju ob popisih.

Fig.1: Population tendencies in the Idrijsko hribovje region (1869-2000).

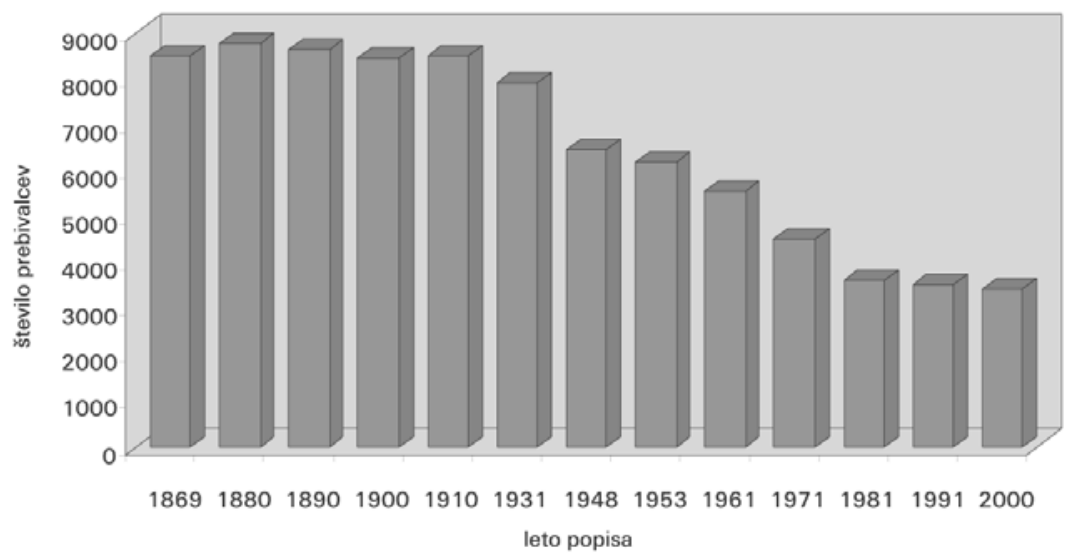

Vir/Source: Krajevni leksikon Slovenije, 1968 in 1995, Statistični urad RS, 2000.

\section{Obdobje po drugi svetovni vojni}

Po drugi svetovni vojni so se gospodarsko razvijala le večja središča, torej Tolmin, Idrija, Cerkno in Spodnja Idrija. Večina prebivalcev Idrijskega hribovja se je še vedno ukvarjala s kmetijstvom, dodatne dohodke pa so pridobivali z izdelovanjem izdelkov domače obrti (kovanje žebljev, izdelovanje suhe robe, pletenje domačih volnenih nogavic, čipkarstvo, suknarstvo, nabiranje gozdnih sadežev in lipovega cvetja, izdelovanje sira in masla). Leta 1961 je bilo v kmetijstvu z gozdarstvom zaposlenih $69 \%$ aktivnih prebivalcev, delež kmečkega prebivalstva pa je znašal 58 \%. Ker pa so delovna mesta $v$ industrijskih naseljih nudila boljšo možnost zaslužka, se je kmečko prebivalstvo iz odročnih naselij začelo seliti v kraje, kjer so dobili zaposlitev, to je v bližnja središča in tudi v ostale bolj razvite kraje po Sloveniji. Zaradi slabih prometnih zvez in cest se ni moglo uveljaviti dnevno vozaštvo. Neugodne reliefne razmere in pomanjkanje finančnih sredstev so 
onemogočale izgradnjo dobrega lokalnega cestnega omrežja. Zaradi tega so bila naselja $v$ težje dostopnih predelih zelo slabo povezana z zaposlitvenimi središči, kar je povzročilo propadanje številnih kmetij na območju Trebuše in v vzhodnem predelu Šentviške planote (Bukovski Vrh, Gorski Vrh, Police), pa tudi na Vojskarski planoti in na območju samotnih kmetij v Masorah in Idrijskih Krnicah. Začela se je intenzivna depopulacija in deagrarizacija teh vasi. Upadanje števila prebivalcev zaradi odseljevanja se je stopnjevalo, kar kažejo tudi indeksi gibanja števila prebivalcev 1953/48 $96,1961 / 53-89,1971 / 61-81$ in 1981/71 - 80.

Število prebivalcev se je na obravnavanem območju v obdobju od leta 1961 do leta 2000 zmanjšalo za 39 , medtem ko se je v Sloveniji povečalo za $24 \%$.

Med popisoma leta 1961 in 1971 se je število prebivalcev zmanjšalo v vseh naseljih, razen v Straži, kjer sta bila le dva prebivalca več kot ob prejšnjem popisu. Največje zmanjšanje je bilo v Gorskem Vrhu (50 \%), sledijo Jagršče (35\%), Polje (31 \%), Gorenja Trebuša (29 \%), Idrijske Krnice (28 \%), Vojsko, Čekovnik in Dolenja Trebuša (26 \%), Bukovski Vrh (25\%), Logaršče in Police (24\%), Srednja Kanomlja, Ponikve in Masore (21\%) itd.

V naslednjem desetletju, med letoma 1971 in 1981, se je število prebivalcev povečalo le na Slapu ob Idrijci (30 \%). Med naselji z upadom števila prebivalcev nad $20 \%$ se pojavljajo skoraj vsa naselja iz prejšnjega obdobja: Gorski Vrh (54\%), Bukovski Vrh (38\%), Stopnik (36 \%), Police in Gorenja Trebuša (35 \%), Vojsko in Logaršče (30 \%), Šentviška Gora (24 \%), Roče, Masore, Jagršče (23 \%), Prapetno Brdo (22 \%) in Daber (21 \%).

Poleg neugodnih gospodarskih razmer, zaradi katerih so se ljudje izseljevali, je tudi potres leta 1976, kljub učinkoviti in hitri obnovi, povzročil, da se je del prebivalstva odselil. Da bi odseljevanje vsaj malo zaustavili, so na Pečinah na Šentviški planoti in v Dolenji Trebuši zgradili dva industrijska obrata. Tradicionalna regionalna politika je namreč $v$ industriji videla jamstvo za gospodarski in družbeni napredek, višji življenjski standard, polno zaposlenost in prenehanje izseljevanja. Spodbujala je mešano industrijskokmetijsko zaposlovanje, kar kažejo podatki o strukturi zaposlenih. Leta 1961 je bilo v sekundarnih dejavnostih zaposlenih le $12 \%$ aktivnih prebivalcev, leta 1991 pa je ta delež znašal že 50 \%. Vendar taka politika ni naredila nič $v$ smeri izboljševanja izobrazbene in kvalifikacijske strukture zaposlenih, to pa je bil eden temeljnih problemov, saj velik del šolane mla- 
dine doma ni dobil ustrezne zaposlitve, zato se je odseljevanje mladih nadaljevalo. Omenjena industrijska obrata sta absorbirala številno kmečko delovno silo iz okoliških naselij, ki pa se kmetijstvu ni odrekla, ampak po delu še vedno kmetujejo (Meze, 1988). Oba obrata še vedno delujeta. V obratu Metalflexa na Pečinah, kjer izdelujejo signalno opremo, je zaposlenih okoli 100 delavcev, EMOK v Dolenji Trebuši, kjer izdelujejo masivno sedežno pohištvo, pa zaposluje 35 delavcev.

$\mathrm{V}$ sedemdesetih, predvsem pa $\mathrm{v}$ osemdesetih letih je bilo zgrajenih in izboljšanih veliko cestnih povezav, s čimer se je izboljšala dostopnost številnih naselij. To pa je bil pogoj za nastanek dnevne migracije prebivalstva iz odmaknjenih naselij. Dobre cestne povezave namreč zmanjšujejo časovno oddaljenost do zaposlitvenih središč, možnost zaposlovanja v obsegu dnevne migracije pa zmanjšuje interes po odseljevanju. Za sodoben način življenja je nujno potrebna tudi opremljenost z osnovno infrastrukturo. Vsa naselja imajo elektriko, vodovod in telefonske priključke ter organiziran odvoz odpadkov. Kljub neugodnim reliefnim razmeram in razpršeni poselitvi, kar močno podraži gradnjo, so v zadnjem desetletju zagotovili manjkajočo osnovno infrastrukturo $v$ vseh naseljih in večino cest asfaltirali. Investicije niso bile zaman, saj so se prebivalstvena gibanja delno normalizirala.

V osemdesetih letih se je število prebivalcev ustalilo in se do leta $2000 \mathrm{ni}$ bistveno spremenilo. Indeks gibanja števila prebivalcev 1991/81 znaša 98, 2000/1991 pa 97. Med letoma 1981 in 1991 se je v kar devetih naseljih število prebivalcev malo povečalo ali ostalo na isti ravni, kar je v primerjavi s prejšnjimi obdobji zelo velik napredek. Gre za nekatera naselja na Šentviški planoti (Polje, Prapetno Brdo, Zakraj, Daber, Gorski Vrh), Slap ob Idrijci, ki leži ob glavni prometnici in je manjše centralno naselje (pošta, avtobusna postaja, gostinski objekti, trgovine) za vasi s Šentviške planote, Srednja Kanomlja, ki že postaja kraj bivanja za mnoge, ki so se naveličali živeti v bližnji Spodnji Idriji ter naselji Šebrelje in Čekovnik, ki sta, kljub oddaljenosti od centrov, $z$ dobro cestno povezavo veliko pridobili. Indeks gibanja števila prebivalcev nad 90 v obdobju 1981-1991 (prebivalstvo se je zmanjšalo za 10 \% ali manj) imajo Bukovski Vrh, Dolenja Trebuša, Idrija pri Bači, Idrijske Krnice, Masore, Pečine, Police, Stopnik in Šentviška Gora. Največji upad števila prebivalcev zasledimo v Jagrščah (32 \%), Logarščah (27\%) in Gorenji Trebuši (24 \%). V skupini naselij, kjer se je število prebivalcev zmanjšalo od 10 do 20 , so naselja Gorenja Kanomlja, Ponikve, Roče, Straža in Vojsko. 
Med letoma 1991 in 2000 je vidna stagnacija ali porast števila prebivalcev v devetih naseljih (Bukovski Vrh, Čekovnik, Gorski Vrh, Idrija pri Bači, Idrijske Krnice, Roče, Srednja Kanomlja, Stopnik in Šebrelje). Padec števila prebivalcev pod $10 \%$ izkazujejo naselja Dolenja Trebuša, Gorenja Kanomlja, Logaršče, Pečine, Polje, Ponikve, Prapetno Brdo, Slap ob Idrijci, Šentviška Gora in Vojsko. Občutnejši padec je v naseljih Police (31 \%), Gorenja Trebuša (26 \%), Straža (21\%), Zakraj (17\%), Masore (16 \%), Daber (14 \%) in Jagršče (11\%). Zdajšnje zmanjševanje števila prebivalcev ni več posledica odseljevanja kot je bilo to značilno za obdobje do konca sedemdesetih let, ampak je posledica zmanjšanega naravnega prirastka. Le-ta pa je rezultat dolgoletnega izseljevanja mladih, saj se je prebivalstvo postaralo, upadla je rodnost in porasla smrtnost.

Vzpodbudno je dejstvo, da se število prebivalcev ne zmanjšuje več tako hitro in v tako velikem deležu naselij kot v prejšnjih obdobjih. K temu so zagotovo pripomogli izboljšani življenjski pogoji, dobre cestne povezave in motorizacija. Čisto okolje in mir kot vse pomembnejši bivalni vrednoti le še pripomoreta $\mathrm{k}$ temu, da se ljudje odločijo za življenje $v$ malo bolj oddaljenih vaseh. Zanimive so predvsem tiste vasi, kjer prometna dostopnost omogoča dnevno migracijo delovne sile in vsakodnevno komunikacijo prebivalstva z regionalnim ali večjim lokalnim središčem. Tam prihaja do stagnacije ali rasti števila prebivalcev, kar se kaže v novogradnjah in obnavljanju starih hiš. Vendar nas to ne sme zavesti k sklepu, da se razmere izboljšujejo. Res je, da se je število prebivalcev skoraj stabiliziralo, vendar starostna struktura prebivalcev ni spodbudna. 
Tabela 2: Število prebivalcev ob popisih in indeksi gibanja števila prebivalcev v Idrijskem hribovju med izbranimi popisnimi obdobji.

Tab. 2: Number of inhabitants and index of population growth in the settlements of Idrijsko hribovje region.

\begin{tabular}{|c|c|c|c|c|c|c|c|}
\hline \multirow[b]{2}{*}{ Naselje } & \multicolumn{2}{|c|}{ Leto popisa } & \multicolumn{5}{|c|}{ Indeksi gibanja števila prebivalcev } \\
\hline & 1869 & 2000 & $\begin{array}{l}\bar{\sigma} \\
\stackrel{\pi}{\sigma} \\
\text { ○ }\end{array}$ & $\begin{array}{l}\bar{\Sigma} \\
\stackrel{-}{\infty} \\
\stackrel{-}{-} \\
=\end{array}$ & $\begin{array}{l}\bar{\infty} \\
\stackrel{5}{\sigma} \\
\text { o } \\
=\end{array}$ & $\begin{array}{l}\bar{\sigma} \\
\text { Oे } \\
\text { ঠ্ণ } \\
\underline{-}\end{array}$ & $\begin{array}{l}\bar{\emptyset} \\
\text { ○े } \\
\stackrel{ }{N}\end{array}$ \\
\hline Bukovski Vrh & 119 & 34 & 75 & 62 & 92 & 103 & 44 \\
\hline Čekovnik & 318 & 149 & 74 & 83 & 101 & 110 & 69 \\
\hline Daber & 90 & 30 & 92 & 79 & 100 & 86 & 62 \\
\hline Dolenja Trebuša & 712 & 289 & 74 & 86 & 93 & 99 & 59 \\
\hline Gorenja Kanomlja & 339 & 143 & 84 & 87 & 88 & 93 & 60 \\
\hline Gorenja Trebuša & 668 & 110 & 71 & 65 & 76 & 74 & 26 \\
\hline Gorski Vrh & 131 & 12 & 50 & 46 & 100 & 109 & 25 \\
\hline Idrija pri Bači & 403 & 322 & 96 & 96 & 92 & 102 & 86 \\
\hline Idrijske Krnice & 172 & 141 & 72 & 88 & 99 & 104 & 65 \\
\hline Jagršče & 105 & 33 & 65 & 77 & 68 & 89 & 30 \\
\hline Logaršče & 262 & 68 & 76 & 70 & 73 & 91 & 36 \\
\hline Masore & 238 & 69 & 79 & 77 & 90 & 84 & 47 \\
\hline Pečine & 312 & 161 & 84 & 93 & 91 & 96 & 69 \\
\hline Police & 158 & 20 & 76 & 65 & 91 & 69 & 31 \\
\hline Polje & 81 & 38 & 69 & 82 & 111 & 95 & 59 \\
\hline Ponikve & 652 & 208 & 79 & 90 & 86 & 95 & 59 \\
\hline Prapetno Brdo & 228 & 118 & 95 & 78 & 106 & 97 & 76 \\
\hline Roče & 181 & 61 & 93 & 77 & 81 & 107 & 63 \\
\hline Slap ob Idrijci & 353 & 256 & 84 & 130 & 107 & 98 & 115 \\
\hline Srednja Kanomlja & 466 & 275 & 79 & 89 & 108 & 116 & 88 \\
\hline Stopnik & 248 & 101 & 80 & 64 & 96 & 103 & 51 \\
\hline Straža & 215 & 118 & 101 & 93 & 87 & 79 & 64 \\
\hline Šebrelje & 888 & 327 & 88 & 86 & 101 & 100 & 76 \\
\hline Šentviška Gora & 331 & 112 & 88 & 76 & 93 & 98 & 61 \\
\hline Vojsko & 742 & 203 & 74 & 70 & 86 & 96 & 43 \\
\hline Zakraj & 84 & 34 & 83 & 82 & 102 & 83 & 58 \\
\hline Skupaj & 8.496 & 3.432 & 81 & 80 & 98 & 97 & 61 \\
\hline
\end{tabular}

Vir/Source: Krajevni leksikon Slovenije, 1968 in 1995, Centralni register prebivalstva, stanje 30.6.2000. 
Slika 1: Gibanje števila prebivalcev v naseljih Idrijskega hribovja, izraženo v odstotkih, v obdobjih 1961-71, 1971-81, 1981-91, 1991-2000.

Fig. 1: Changes in the number of inhabitants in the settlements of Idrijsko hribovje region, expressed in percents, in the period 1961-71, 1971-81, 1981-91, 1991-2000. 


\section{Staranje prebivalstva}

$Z$ indeksom staranja (razmerje med prebivalstvom, starim nad 65 let in mlajšim od 14 let) ugotavljamo, v kolikšni meri se prebivalstvo stara, starostna sestava pa tudi nakazuje bodoče gibanje prebivalstva.

Delež mladega prebivalstva v Idrijskem hribovju je leta 1961 predstavljal $28 \%$ vsega prebivalstva, leta $199119 \%$ in leta 2000 le še $15 \%$. Delež nad 65 let starega prebivalstva pa je bil leta $196112 \%$, leta 1991 in 2000 pa $20 \%$. Delež mladega prebivalstva se je v štiridesetih letih zaradi odseljevanja in zmanjšanja rodnosti skoraj prepolovil, močno pa se je povečal delež starega prebivalstva. Prebivalstvo Idrijskega hribovja je iz tipa mladega, progresivnega prebivalstva $v$ štirih desetletjih prešlo $v$ star, regresivni tip prebivalstva. Tako spreminjanje starostne sestave je $v$ skladu s splošnim in gospodarskim razvojem, vendar je $v$ Idrijskem hribovju že prišlo do kritične točke, ko je prebivalstvo začelo odmirati.

Pri umrljivosti in rodnosti v slovenskih razmerah bi indeks staranja okoli 40 pomenil normalno oziroma mlado starostno sestavo. Ob popisu leta 1991 je bil indeks staranja vsega prebivalstva Slovenije 53, kar pomeni, da prebivalstvo ni več mlado. Pri rodnosti, kakršna je bila $v$ začetku devetdesetih let, je indeks staranja 72 ali več pomenil, da tako slaba starostna sestava ne zagotavlja več obnavljanja prebivalstva oziroma ohranjanja nespremenjenega števila. $V$ območjih, kjer prevladuje tako visok indeks staranja, je bil že presežen t.i. demografski prag in bo število prebivalcev $v$ prihodnjih letih nazadovalo, tudi če ne bi bilo odseljevanja (Kovačič, 2000). Porast števila prebivalcev je možen samo $s$ povečanjem rodnosti ali z doseljevanjem. Omenjeni indeks kaže, da je bil demografski prag prebivalstva v Idrijskem hribovju leta 1991 krepko presežen, saj je znašal kar 106, natančno dvakrat več kot je bila vrednost za Slovenijo. $Z$ vidika obnavljanja prebivalstva sta imeli relativno ugoden indeks staranja le dve naselji, Slap ob Idrijci in Srednja Kanomlja. Prvo leži ob glavni prometnici proti Tolminu, drugo pa predstavlja suburbanizacijsko območje Spodnje Idrije. Nekatera naselja se bodo v prihodnosti izpraznila, če ne bo priseljevanja oziroma če se ne bo povečala rodnost, kar pa je brez priselitve mladih, glede na neugodno starostno sestavo, nemogoče. $V$ 24. naseljih je bil demografski prag leta 1991 presežen, $v$ nekaterih večkrat, npr. v Gorenji Trebuši za skoraj šestkrat, v Logarščah petkrat, v Policah štirikrat, v Gorskem Vrhu in Jagrščah trikrat. 
Tabela 3: Indeksi staranja prebivalstva v letih 1961, 1991 in 2000 za naselja v Idrijskem hribovju.

Tab. 3: Ageing index in the years 1961, 1991, 2000 in the settlements of Idrijsko hribovje region.

\begin{tabular}{|l|c|c|c|}
\hline Naselje & IS 1961 & IS 1991 & IS 2000 \\
\hline Bukovski Vrh & 35 & 116 & 225 \\
\hline Čekovnik & 25 & 108 & 100 \\
\hline Daber & 39 & 112 & 71 \\
\hline Dolenja Trebuša & 60 & 82 & 119 \\
\hline Gorenja Kanomlja & 39 & 103 & 450 \\
\hline Gorenja Trebuša & 50 & 431 & 150 \\
\hline Gorski Vrh & 61 & 200 & 161 \\
\hline Idrija pri Bači & 46 & 95 & 112 \\
\hline Idrijske Krnice & 60 & 75 & 100 \\
\hline Jagršce & 13 & 200 & 209 \\
\hline Logaršče & 87 & 386 & 175 \\
\hline Masore & 32 & 136 & 166 \\
\hline Pečine & 51 & 96 & 1100 \\
\hline Police & 44 & 300 & 100 \\
\hline Polje & 53 & 77 & 159 \\
\hline Ponikve & 26 & 141 & 128 \\
\hline Prapetno Brdo & 39 & 92 & 183 \\
\hline Roče & 38 & 90 & 119 \\
\hline Slap ob Idrijci & 65 & 57 & 62 \\
\hline Srednja Kanomlja & 34 & 48 & 126 \\
\hline Stopnik & 44 & 100 & 291 \\
\hline Straža & 55 & 128 & 94 \\
\hline Šebrelje & 48 & 92 & 151 \\
\hline Šentviška Gora & 41 & 185 & 167 \\
\hline Vojsko & 37 & 146 & 131 \\
\hline Zakraj & 28 & 90 & \\
\hline Skupaj & 44 & & \\
\hline
\end{tabular}

Vir/Source: Lastni izračuni iz popisov prebivalstva za leto 1961, 1991 in podatkov Statističnega urada RS o prebivalstvu za leto 2000.

V letu 2000 se je razmerje med deležem starih in mladih prebivalcev še poslabšalo. Vrednost indeksa staranja prebivalstva za Idrijsko hribovje se je povečala na 131, omeniti pa je treba, da se je močno povečala tudi vrednost indeksa za Slovenijo in sicer na 89. To pomeni, da se naša družba hitro stara. Indeksi staranja prebivalstva za leto 2000 so v primerjavi z letom 1991 večji v 20 naseljih. V Policah je indeks staranja 1100, kar pomeni, da je starega prebivalstva kar enajstkrat več kot mladega, v Gorenji Trebuši štirikrat, v Straži trikrat, v Bukovskem Vrhu in Logarščah pa dvakrat. Stanje 
se je v primerjavi z letom 1991 izboljšalo v Čekovniku, Dabru, Gorskem Vrhu, Jagrščah, Logarščah in na Šentviški Gori. Vendar v nobenem naselju, z izjemo Srednje Kanomlje in Dabra, vrednost indeksa staranja ne zagotavlja lastne reprodukcije prebivalstva.

Staranje prebivalstva pomeni tudi zmanjševanje števila za delo sposobnih ljudi, saj prebivalstvo z velikim deležem starih nima demografske rezerve za zapolnitev vrzeli, ki nastaja $v$ delovno aktivni populaciji, kar lahko pomeni velik socialni problem in nadaljevanje zaraščanja kulturne pokrajine. Zadosten delež mladih ljudi je namreč odločilen dejavnik nadaljnjega obstoja in razvoja naselij. Vse večji delež starejših skupin prebivalstva na nekem območju pa kaže upadanje njegovega gospodarskega, političnega in kulturnega potenciala ter večanje socialne odvisnosti območja. Rezultati analize indeksa staranja $v$ naseljih Idrijskega hribovja so zaskrbljujoči. Območje nujno potrebuje razvojno strategijo, ki ga bo oživila.

\section{Nekatere posledice neugodnih demografskoh gibanj}

\section{Delež kmečkega prebivalstva}

Hkrati s procesi odseljevanja in intenzivne dnevne migracije $v$ urbane, zaposlitvene centre se je odvijala tudi deagrarizacija. Delež kmečkega prebivalstva se je z 58 \% leta 1961 zmanjšal na 16 \% leta 1991, kar je še vedno za skoraj 1,5-krat več kot je bilo povprečje za Slovenijo in relativno veliko za pokrajino, ki ima tako neugodne naravne pogoje za kmetijstvo. Le-to je postalo samo še dopolnilna dejavnost, s katero se ukvarja predvsem ostarelo prebivalstvo. Zaradi tega se vidno spreminja tudi struktura rabe kmetijskih površin. Kar 67 \% Idrijskega hribovja že porašča gozd (Černe, 1998), njegov delež pa se zaradi zaraščanja kulturne pokrajine še povečuje.

\section{Izobrazbena sestava prebivalstva}

Posledica velikega deleža starega prebivalstva je tudi njegova slaba izobrazbena sestava. Večinoma gre za kmečko ali polkmečko prebivalstvo, ki je delalo in še vedno dela kot nekvalificirana ali priučena delovna sila $v$ tovarnah, po prihodu iz službe pa še na kmetiji. Taka celodnevna zaposlitev ni dopuščala nadaljevanja šolanja in dodatnega izobraževanja. Leta 1991 je bilo brez izobrazbe 2,8 \% prebivalcev Idrijskega hribovja (Slovenija 0,6\%), 
z nedokončano osnovno šolo 34 \% (Slovenija 17,3 \%), z osnovnošolsko izobrazbo 37 \% (Slovenija 30,3 \%), s srednješolsko 23 \% (Slovenija 43 \%), z višje in visokošolsko pa le slaba $2 \%$ (Slovenija 8,9 \%). Nepismenih je bilo skoraj 3 \% (Slovenija 0,4\%).

Ustrezna starostna in izobrazbena sestava prebivalstva sta odločujoča dejavnika splošnega in gospodarskega razvoja. V Idrijskem hribovju sta obe izredno slabi in ne zagotavljata, da se bodo na obravnavanem območju lahko razvile dejavnosti, ki zahtevajo izobraženo in kvalificirano delovno silo. Gre predvsem za terciarne in kvartarne dejavnosti, ki v regijah z ugodnimi demografskimi in gospodarskimi gibanji zaposlujejo največji delež aktivnega prebivalstva. Te dejavnosti prinašajo največ profita in se lažje prilagajajo spremembam na trgu kot sekundarne in primarne. Leta 1991 je bilo v Idrijskem hribovju v terciarnih in kvartarnih dejavnostih zaposlenih le $18 \%$ aktivnih prebivalcev, v Sloveniji pa $46 \%$. Več zaposlenih v omenjenih dejavnostih pomeni več storitev in boljšo oskrbo prebivalstva.

Prebivalci vidijo prihodnost Idrijskega hribovja v razvoju okolju prijaznega turizma in $v$ pridelovanju zdrave hrane. Najbolj učinkovito bi bilo kombiniranje kmetijstva $z$ dopolnilnimi dejavnostmi, od katerih velja tu posebno izpostaviti že omenjeni turizem, gostinstvo in tradicionalne obrti. Pri uvajanju novih dejavnosti pomeni največjo oviro pomanjkanje začetnega kapitala in znanja oziroma ustrezno izobražene delovne sile. Zato večino ljudi niti ne zanima razvoj novih dejavnosti, poleg tega pa $v$ njih ne vidijo zadostnega zaslužka (anketa, 2001).

Osnovne šole so "servis" prebivalstva, pa tudi vzdrževalec poselitve.

Leta 1961 je bilo na območju veliko otrok, kar kažejo nizki indeksi staranja prebivalstva. Temu ustrezno je bila razporejena mreža osnovnih šol. Osnovno šolo je imelo petnajst naselij. Popolna osnovna šola je bila $v$ Gorenji Trebuši, podružnične šole s štirimi razredi so bile v Bukovskem Vrhu, Dolenji Trebuši, Stopniku in na Idriji pri Bači, Pečinah, Ponikvah, Slapu ob Idrijci, Šentviški Gori. Podružnice z dvema razredoma so bile v Čekovniku, Idrijskih Krnicah, Jagrščah, Srednji Kanomlji, Šebreljah in na Vojskem (Krajevni leksikon Slovenije, 1968). 
Slika 2: Mreža šol v Idrijskem hribovju leta 1961 in 2001.

Fig. 2: School network in Idrijsko hribovje region in the years 1961 and 2001.

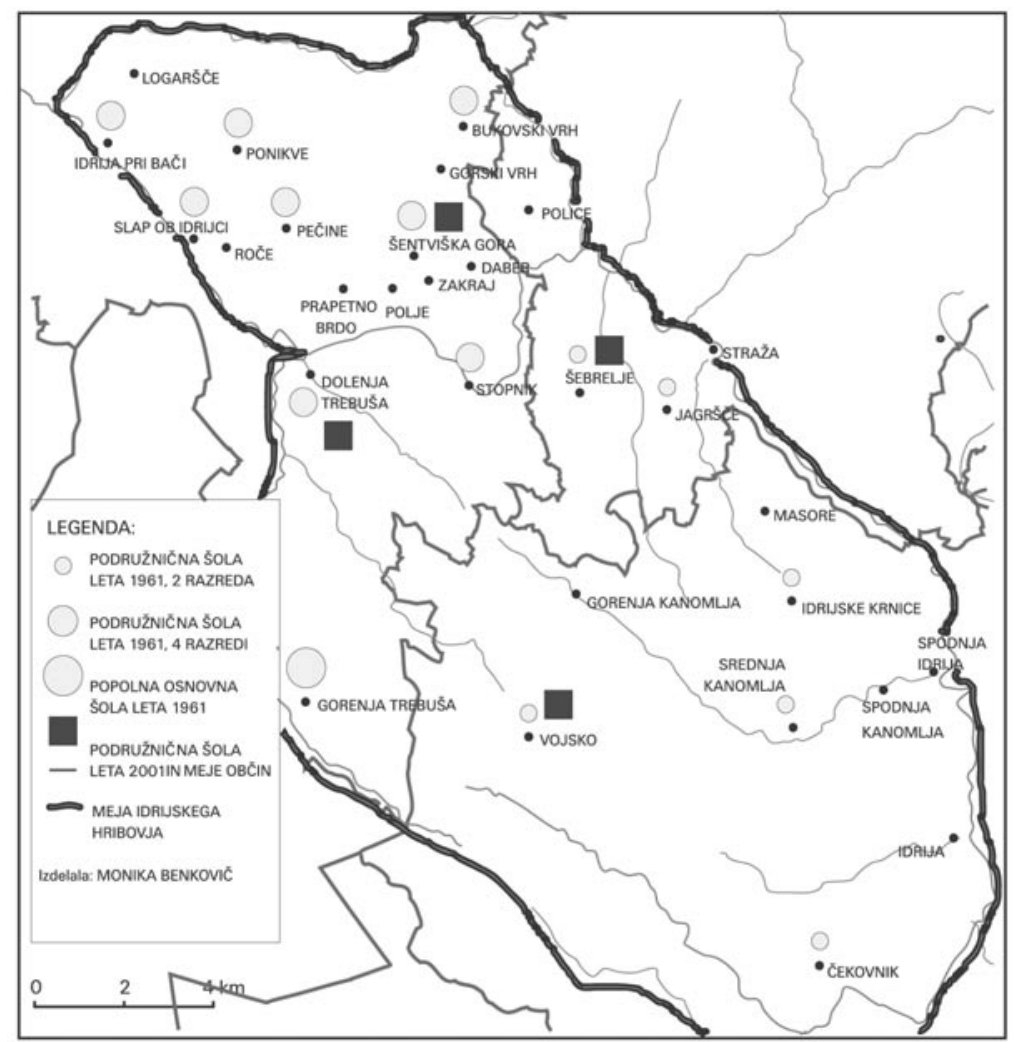

Zaradi že omenjenih demografskih gibanj se je število otrok stalno zmanjševalo, vzporedno pa se je krčila tudi mreža šol. Seveda ni vzrok za zapiranje šol le zmanjšanje števila otrok, ampak tudi radikalne spremembe v okviru reforme šolskega sistema. Prišlo je do racionalizacije obstoječe šolske mreže, ki je šla v korak z deagrarizacijo in depopulacijo prebivalstva ter z izboljšanjem prometne infrastrukture. Uvajati so začeli prevoze učencev avtobusi. Danes so na celem območju le štiri podružnične osnovne šole: v Šebreljah, Dolenji Trebuši, na Šentviški Gori in Vojskem. Šolo v Srednji Kanomlji so letos zaprli. Do konca letošnjega šolskega leta je bila šola v Šebreljah štiriletna, zdaj bo le triletna, v ostalih treh podružnicah pa lahko otroci zaključijo prve štiri razrede osnovne šole (terensko delo, stanje julij 2001). 
Za vožnjo otrok v šolo je v večini naselij dobro poskrbljeno, saj jih vozijo s kombijem ali s šolskim avtobusom. Otroci iz Šebrelj, Straže, Jagršč in delno iz Stopnika se vozijo v šolo v Cerkno. Pod matično šolo v Cerkno spada tudi naselje Police, vendar trenutno tam ni šoloobveznih otrok. Z Vojskega in Čekovnika hodijo v Idrijo, iz Gorenje in Srednje Kanomlje ter Masor in Idrijskih Krnic pa v Spodnjo Idrijo. Iz Gorenje Trebuše in delno iz Stopnika hodijo najprej štiri leta v Dolenjo Trebušo, potem pa iz vseh treh naselij na Most na Soči. Otroci iz naselij na Šentviški planoti (Bukovski Vrh, Gorski Vrh, Daber, Zakraj, Polje, Prapetno Brdo, Pečine in Ponikve) končajo prva štiri leta šolanja na Šentviški Gori, naslednja leta pa na Mostu na Soči, kamor se ves čas šolanja vozijo tudi otroci iz Roč, Slapa ob Idrijci in Idrije pri Bači. Šoloobvezni otroci z Logaršč hodijo v podružnico s tremi razredi (do konca šolskega leta 2000/01 je imela štiri razrede) v Podmelec v Baško grapo, potem pa šolanje nadaljujejo na Mostu na Soči.

Mnogi menijo, da bi moralo biti čim več podružničnih šol, ne glede na število otrok. Otroci ne bi smeli vsak dan porabiti več ur za pot v šolo. Zavedati pa se moramo, da šola ni le središče izobraževanja in ostalih aktivnosti otrok, ampak predstavlja tudi pomembno kulturno središče. S tem se strinjajo tudi na občinah. Pri tem je najtežje najti učitelje, ki so se pripravljeni vsak dan voziti na delo v podružnice. Poleg tega mnogi pravijo, da je pouk na podružničnih šolah manj kakovosten, ker so učitelji preobremenjeni, saj predavajo za več stopenj hkrati.

\section{Oskrba prebivalstva}

Sodobno življenje pomeni tudi ustrezen dostop do storitvenih dejavnosti in javnih služb, ki so osredotočene $v$ centralnih naseljih različnih stopenj. Mednje spadajo različne terciarne (trgovine, storitvene obrti, denarni zavodi in poslovne storitve) in kvartarne dejavnosti (šolstvo, zdravstvo, socialno skrbstvo, uprava, družbene organizacije) (Geografske atlas Slovenije, 2000). Omenjene dejavnosti imajo prebivalci Idrijskega hribovja na voljo v občinskih središčih (Idrija, Cerkno, Tolmin), v Spodnji Idriji in na Mostu na Soči. Cerkno, Most na Soči in Spodnja Idrija so centralna naselja druge stopnje in imajo popolno osnovno šolo, trgovino z živili, gostilno, pošto, zdravstveno ambulanto, policijsko postajo (Spodnja Idrija je nima), banko, bencinski servis, lekarno in nekatere specializirane obrti in trgovine. Tolmin in Idrijo uvrščamo med centralna naselja tretje stopnje, ki poleg navedenih dejavnosti nudijo še zdravstveni dom, kino, hotel, knjižnico (ima jo tudi 
Cerkno) in izpostavo temeljnega sodišča. Obe naselji imata tudi srednjo šolo. Zahtevnejše storitve kot so bolnišnica, javne službe in srednje šole morajo prebivalci poiskati v Novi Gorici in Ljubljani.

$\mathrm{Na}$ proučevanem območju so štiri naselja (Geografski atlas Slovenije, 2000) opredeljena kot centralna naselja najnižje stopnje: Šentviška Gora, Šebrelje, Vojsko in Dolenja Trebuša. Le-ta naj bi prebivalcem nudila najosnovnejše storitve, ki jih uporabljajo redno ali pogosto, to pa so nepopolna ali popolna osnovna šola, trgovina z živili in gostilna. Vendar jih vsa naselja ne nudijo; Šentviška Gora nima trgovine z živili in Šebrelje nimajo gostilne. Centralno naselje za naselja s Šentviške planote predstavlja tudi Slap ob Idrijci s trgovino z živili in nekaterimi specializiranimi trgovinami (prodaja avtomobilov), gostilno in pošto. Trgovino z živili imajo poleg že naštetih še naselja Straža, Ponikve in Pečine, gostilno pa Stopnik, Srednja Kanomlja, Straža, Pečine in Gorenja Trebuša. V Jagrščah imajo bife, ki je odprt le ob koncu tedna. Zanimivost je potujoča trgovina, ki enkrat tedensko obišče naselja Šentviška Gora, Daber, Prapetno Brdo in Zakraj na Šentviški planoti. Namenjena je predvsem oskrbi starejših ljudi, ki sami ne morejo po nakupih v lokalna središča. Ljudem, ki se dnevno vozijo na delo v zaposlitvena središča, nakup živil ne predstavlja težav. Tisti, ki se ne vozijo na delo, nakupijo za več dni skupaj, na kar so se že navadili. Težave imajo le starejši brez lastnega prevoza, ki morajo za pomoč prositi sosede; rednih avtobusnih povezav je namreč zelo malo. Avtobusno postajo, kjer ustavlja redna avtobusna linija, imajo le naselja ob glavni cesti med Idrijo in Tolminom; to so Straža, Stopnik, Slap ob Idrijci in Idrija ob Bači. Prebivalci ostalih naselij se lahko poslužujejo avtobusa, ki vozi delavce in šolarje.

Z anketiranjem je bilo ugotovljeno, da prebivalci $v$ naselju bivanja najbolj pogrešajo živilsko trgovino ali pa si želijo, da bi bila obstoječa bolje založena. Tudi gostilna bi po mnenju ljudi morala biti v skoraj vsakem naselju, saj pomeni kraj, kjer se vaščani zbirajo in družijo. Zelo veliko jih poudarja, da ni dovolj kulturnih prireditev in družabnega življenja, kakršnega so bili vajeni nekoč. Mnogi, zlasti starejši, si želijo dostopnejšo zdravstveno oskrbo in pogostejše avtobusne povezave (anketa, 2001).

Zaradi razpršene poselitve ni dovolj, da se storitvene dejavnosti koncentrirajo le v večjih središčih. Tiste, ki jih ljudje potrebujejo vsak dan in pogosto, bi se lahko usmerile v primerno izbrane vasi, ki bi kot manjši centri oskrbovale bližnja naselja. Tako bi se obnovil določen stavbni fond in ponudilo bi se nekaj novih delovnih mest. Res je, da obstoj nekaterih dejavnosti v 
majhnih naseljih oziroma $v$ naseljih $z$ majhnim zaledjem ni ekonomsko upravičen, je pa zelo pomemben za zagotavljanje enakovrednih pogojev bivanja in s tem ohranjanje poselitve.

\section{Zaključek}

Naselja Idrijskega hribovja je po letu 1961 zajela močna depopulacija, ki je trajala vse do osemdesetih let, ko se je število prebivalcev skoraj ustalilo. Vzrok sedanjega upadanja števila prebivalcev je negativni naravni prirastek, ki je posledica izredno slabe starostne sestave prebivalstva. Le-ta predstavlja temelj nadaljnjega demografskega razvoja. Trenutna starostna sestava $v$ večini naselij ne omogoča lastne reprodukcije prebivalstva, ki pa je osnovno gibalo razvoja $v$ vsaki pokrajini. Predvidevam lahko, da se bo število prebivalcev tudi v prihodnje zmanjševalo. Nekatera težje dostopna in oddaljena naselja se bodo izpraznila, naselja, kjer dnevna komunikacija z oskrbnimi in zaposlitvenimi centri ne predstavlja večjih težav, pa se bodo ohranila. V nekaterih med njimi je $v$ zadnjem desetletju opazen rahel porast števila prebivalcev.

\section{IDRIJSKO HRIBOVJE REGION AS AN EXAMPLE OF DEMO- GRAPHICALLY ENDANGERED AREA}

\section{Summary}

Idrijsko hribovje is a part of prealpine hilly region. It is a transitive region between the Alps and the Dynaric karst. The landscape is sparsly inhabitated due to uneven terrain, poor natural conditions for economic development and remote position. In the year 2000 the population density was only 15 inhabitants/km2, which is 6,5- times less than Slovenian average. The area consists of three municipalities: Idrija, Tolmin and Cerkno and it extends over $239 \mathrm{~km} 2$. The basis of this research was the analysis of settlements. According to the law for stimulation of development in demographically endangered areas 21 out of 26 settlements are classified as demographically endangered.

The aim of the article was to analyse the growth of population, to determine the ageing index and to point out the reasons for past and present demographic processes and the influence these processes have on further 
development. The following indicators were included in the research:

- changes in the number of inhabitants between 1869 - 2000, with special emphasis on the period 1961 - 2000;

- age structure of population in the years 1961, 1991 and 2000 (ageing index);

- share of rural population in the years 1961 and 1991;

- educational structure of population in the year 1991;

- network of primary schools in the years 1961 and 2001;

- spatial organization of central settlements and their equipment (tertiary and quartiary activities).

In the year 1869, when the first census was carried out, 8.496 inhabitants lived on the territory of Idrijsko hribovje. The region achieved its maximum population level in the year 1880 (8.807), when the population density was of 41 inhabitants $/ \mathrm{km} 2$. After a short period of stagnation depopulation process began due to the emigration to the United States, accelerated by poor natural conditions for agriculture and unfavourable economic and political conditions (the region belonged to Italy between the First and the Second World War). Another reason for the decrease in population number represent demographic losses during the both World Wars.

After the Second World War the period of industrialization began and differences between regions in Slovenia started to grow. The economic development was concentrated in cities, where incomes, provided by jobs in non-agricultural activities, were higher than those in agriculture. Bad traffic connections hindered daily commutery, thus forcing the population to move to place with better employment opportunities. The biggest changes in the number of inhabitants took place in the sixties and seventies, when 25 out of 26 settlements were undergoing depopulation. During the 1961 - 1971 period the population fell by over $19 \%$ and in the 1971 - 1981 period by another $20 \%$. The most intense depopulation was in remote hilly villages. By improved accesibility and infrastructure the depopulation was strongly reduced. In the eighties the number of inhabitants fell by only $2 \%$ and in the nineties by another $3 \%$. The cause of current depopulation is no longer emigration, but rather negative population growth, caused by extremely unfavourable age structure. In some settlements the number of inhabitants even increased a little. Of special interest are settlements, where traffic accesibility enables daily communication with regional or local centres.

During the years 1961 and 2000 the number of inhabitants in Idrijsko hri- 
bovje region was reduced for $39 \%$, whereas in Slovenia it increased for 24 $\%$. Over two decades of very intense emigration of primarly young people are reflected in accelerated process of ageing of the population. In the most of the settlements the proportion of old people (over 65 years) is higher than the proportion of young people (under 15 years). Such an age structure makes the reproduction of population impossible, which means further depopulation along with ageing of the population.

The demographic processes mentioned above and some radikal changes in school system are the reason for the constant reduction in the number of children and consecutively for reduction in the school network as well. The number of schools fell from 15 in the year 1961 ( 1 complete school - eight years and 14 dislocated schools - two or four years) to only 4 (dislocated schools - four years) in the year 2001. School network is an important factor of the preservation of settlements. Of the same importance are central settlements, which also contribute to better living conditions. Regarding supply and employment, the inhabitants of Idrijsko hribovje region are mostly connected to Idrija, Spodnja Idrija, Tolmin, Cerkno and Most na Soči. In the examined area there are only 4 small central settlements and even those do not meet the required standards of basic tertiary and quartiary activities (grocery, restaurant, primary school).

Along with the depopulation and daily migration to the urban employment centres the deagrarization also took place. The share of rural population was reduced from $58 \%$ in the year 1961 to $16 \%$ in the year 1991. The agriculture occupies mostly elderly people. This is the reason for changes in the structure of use of agricultural land, which reflects in abandoning of cultivation and overgrowing of cultural landscape.

The educational structure is below the average in the Republic of Slovenia as well. Proper age and educational structure of the population represent conditions for the future development of the region. The Idrijsko hribovje region urgently needs a developmental strategy for its revival. It is necessary to preserve a cultural landscape and to attract young people to imigrate to the region. Beside that improvement of services and development of new economic activities is also of great importance. The future for the region is in environmental friendly tourism and production of healthy food. 


\section{Literatura in viri}

Černe, A., 1998. Idrijsko hribovje. V: Slovenija - pokrajine in ljudje. Ljubljana, Mladinska knjiga, str. 342-351.

Državljani RS po občini in naselju stalnega prebivališča, starostnih skupinah in spolu, 30.6.2000, Statistični urad Republike Slovenije, Ljubljana.

Geografija Slovenije. 1998. Gams, I., Vrišer, I. (ur.). Ljubljana, Slovenska matica, 501 str.

Geografski atlas Slovenije. 2000. Ljubljana, Državna založba Slovenije, 360 str.

Kovačič, M., 1994. Težišča in problemi pri razvoju podeželja v Sloveniji. V: Pristop k razvoju podeželja, zvezek 2. Ljubljana, Biotehniška fakulteta, Oddelek za agronomijo, str. 1-8.

Kovačič, M., 2000. Razvojno-tipološka členitev podeželja v Republiki Sloveniji. Ljubljana, Biotehniška fakulteta, Oddelek za agronomijo, Inštitut za agrarno ekonomiko, 117 str.

Krajevni leksikon Slovenije, knjiga 1- Zahodni del Slovenije. 1968. Savnik, R.(ur.). Ljubljana, Državna založba Slovenije, 487 str.

Krajevni leksikon Slovenije. 1995. Kladnik, D., Perko, D., Orožen Adamič, M. (ur.). Ljubljana, Državna založba Slovenije, 638 str.

Melik, A.,1960. Slovensko Primorje. Ljubljana, Slovenska matica, 547 str.

Meze, D., 1988. Kmetije na Šentviški planoti in v Trebuši. Geografski zbornik, I. XXVIII, str. 89-125.

Pečar, J., 1998. Kriteriji za določitev območij s posebnimi razvojnimi problemi v Sloveniji. V: Statistična podpora pogajanjem Republike Slovenije z Evropsko Unijo in strukturni skladi. Zbornik Statističnih dnevov v Radencih od 23.-25.11.1998. Ljubljana, Statistični urad Republike Slovenije, str. 259-277.

Pelc, S., 1996. The village Vojsko - an example for the implementation of integral rural development in Slovenia. V: Development issues in marginal regions II. Mendoza, str. 195-206.

Popis prebivalstva 1961 in 1991, Statistični urad Republike Slovenije, Ljubljana.

Ravbar, M., 2000. Regionalni razvoj slovenskih pokrajin. V: Regionalni razvoj v Sloveniji. Ljubljana, Inštitut za geografijo. (Geographica Slovenica, I. 33, št.II, str. 9-81) 
Uredba o območjih, ki se štejejo za demografsko ogrožena območja v Republiki Sloveniji. 1999. Uradni list RS, 19, 60.

Zakon o spodbujanju razvoja demografsko ogroženih območij v Republiki Sloveniji. 1990. Uradni list RS, 48.

Zakon o spodbujanju skladnega regionalnega razvoja.1999. Uradni list RS, 60. 